\title{
Explores the Specific Context of Financial Statement Fraud Based on Empirical from Indonesia
}

\author{
Muhammad Ikbal $^{1,2}$, Irwansyah Irwansyah ${ }^{2}$, Ardi Paminto ${ }^{3, *}$, Yana Ulfah $^{2}$, Dio Caisar Darma ${ }^{4}$ \\ ${ }^{1}$ Doctoral Program of Accounting, Faculty of Economics and Business, Brawijaya University, Malang, Indonesia \\ ${ }^{2}$ Department of Accounting, Faculty of Economics and Business, Mulawarman University, Samarinda, Indonesia \\ ${ }^{3}$ Department of Management, Faculty of Economics and Business, Mulawarman University, Samarinda, Indonesia \\ ${ }^{4}$ Department of Management, Sekolah Tinggi Ilmu Ekonomi Samarinda, Samarinda, Indonesia
}

Received May 18, 2020; Revised July 10, 2020; Accepted July 20, 2020

Copyright $\bigcirc 2020$ by authors, all rights reserved. Authors agree that this article remains permanently open access under the terms of the Creative Commons Attribution License 4.0 International License

\begin{abstract}
We explored the specific context of financial statements of fraud in Indonesia based on empirical evidence. We also explored the lineament of fraudulent financial reporting in Indonesia. This research is important because it will greatly assist the auditor in understanding the pattern and form of fraud, to be able to detect and report these illegal actions. We used a mixed-method of surveying and observation to collect data. Our finding is that the financial statement of fraud is a case throughout the world. The most dominant fraud in Indonesia is the problem of recognition of inappropriate income and secondly related to the improper valuation of assets. We also found something else, that the higher the auditor's experience, the easier it was to find and detect fraud on financial statements and that auditors who hold CFE certificates found more cases of financial reporting fraud during the audit process compared to auditors without CFE certificates. This research contributes to the development of literature by broadening the understanding of academics and practitioners of various fraud profiles that are generally carried out in Indonesia.
\end{abstract}

Keywords Financial, Statement Fraud, External Auditor, Auditor Experience

JEL: G2, G3, M4

\section{Introduction}

The main issue of this research is related to fraud in the company's financial statements. The issue of fraud has become a global issue and a major problem for stakeholders and parties related to the company. Analysis results from ACFE that fraud in financial reporting is a type of fraud that is very expensive, meaning that if combined it can produce a very fantastic figure, an average loss of US $\$ 800,000$. Fraudulent financial reporting requires three simultaneous circumstances: opportunity, a motive for doing so, and willingness on the part of the offender (Snyder et al., 2009). Opportunity is one of the most important things among these conditions because without opportunity even the most motivated and willing potential perpetrators cannot commit fraud. Shortly, the opportunity is a prerequisite needed for fraud. Agency theory has shown that the CEO's role is very conducive to such opportunities because the broad separation of ownership from corporate control contributes to the goals and information asymmetry between CEOs who control the company and their shareholders (Berle \& Means, 1932).

Fraud can happen anywhere, large multinational companies also never experienced fraud in the financial statements. Since the beginning of the second quarter of 2017, there has been an issue of accounting fraud at British Telecom. This British giant company experienced an accounting fraud scandal in one of its lines of business in Italy. As with other accounting fraud scandals, fraud in British Telecom has an impact on its public accountants. This time the affected is the Price Waterhouse Coopers $(\mathrm{PwC})$ which is a well-known public Accounting Firm in the world the big four. In Indonesia, the Ministry of Finance and the Financial Services Authority (OJK) agreed to find fraud in the 2018 annual financial report of the state-owned company PT Garuda Indonesia. For this reason, the two regulators agreed to impose penalties on public accountants, public Accounting Firms and companies. The case was discovered by the Commissioners, according to them, Garuda Indonesia should have recorded a loss of USD 244.95 million in 2018. But in the financial statements it was recorded throughout 
2018 the company posted a net profit of USD 809.84 thousand, a sharp increase from 2017 which lost USD 216.58 million.

One way to solve the problem is to find out how the fraud was committed. Thus this research is to explore the patterns of fraud committed by the management of corporate financial statements in Indonesia. This research is very important for several reasons, first; this research is very useful for auditors in finding and detecting modes of fraud, both intentional and in nature of administrative errors, then this research can be a reference for companies in preparing a prevention plan for illegal actions (Wells, 2005). This type of fraud can be easily detected when an auditor clearly understands the forms and motives of fraud (Jones, 2011). The second reason, knowledge about fraud is very useful for stakeholders. Business practitioners, for example, when they want to start a new business would be able to make a precautionary measure on investments made by companies to regulators will easily determine the focus on which cases need to be strengthened by the rule of law. For investors and customers need to make informed decisions about where to direct their own money, both to invest and buy company products. The mass media wants context and direction to help raise awareness and awareness of this problem to the public. This research contributes to the development of literature by broadening the understanding of academics and practitioners of various fraud profiles that are generally carried out in Indonesia. The wrongdoing of financial reporting is a context that receives minimal attention to scientific development, especially accounting and financial management. There is something unique from this research that all information is dug deeper from external auditors with an in-depth interview mechanism. Many research results raise more cases of the impact of fraud or fraud motivation as discussed in the fraud triangle theory, not the specific context or based on empirical evidence as in this study.

Some of the previous studies that revealed cases related to financial reporting fraud during the audit took place in several developing countries (for example Malaysia, Nigeria, and including Indonesia). This happens because some auditors do not have CFE certificates and that is very risky. On the other hand, those who have worked with CFE certificates do not find many cases to detect financial statements. The need for good control, fundamental management principles, quality audits, and complex understanding can at least minimize fraud (Mohamed \& Handley-Schachelor, 2014; Suyanto, 2009; Omoolorun \& Abilogun, 2017). The literature has been taken into consideration and reference for this study.

Our study has the following paper posture, First, we review the relevant literature regarding fraudulent financial reporting. Next, we develop theories about how the auditor's experience relates to the ability of possible fraud in company financial reporting. Next, we explain how the methodology we use, the method of data collection using surveys, and in-depth interviews. We discuss the findings of the survey and interview that are discussed in detail each item forms and the context of fraud in financial reporting. We conclude with a discussion of the results of our research and its implications for future research and practice.

\section{Theoretical Framework}

The preparation of financial statements involves many parties, even at the time of the examination, it even involves an external auditor. Fraud in corporate financial reporting certainly involves intentional, misstated items, including negligence on disclosure of income and asset items, usually financial statements made specifically for the intention of fraud will be presented to users so they are not easily detected by users (Hopwood et al., 2008) and based on the findings of Brennan \& McGrath (2007) management's tendencies are the main actors because they have full control over the financial statements. As well as a study by ACFE (2005) that most fraud cases are committed by executives and top management. Financial reporting fraud can be done in various ways including recognition of improper income, hiding costs, and liabilities, valuing assets according to the rules, and presentation and disclosure not by the rules (Wells, 2005). However, the recognition of inappropriate income and misuse of assets appears to be the dominant pattern of fraud in the annual financial statements (COSO, 1987). Elder et al. (2010) state that there are three main types of income manipulation: recording fictitious income, recognition of premature income, and manipulation of income period. We have carried out our search of various literature and previous studies, various methods will be summarized in the following Table 1. 
Table 1. How to recognize income that is not appropriate

\begin{tabular}{|c|c|c|}
\hline No. & Techniques & Sources \\
\hline 1 & Falsification of Documents sale and delivery of goods & Coenen (2009), Hopwood et al. (2008) \\
\hline 2 & Percentage of completion of misstatements & Coenen (2009), Hopwood et al. (2008) \\
\hline 3 & Income recorded is gross revenue, not net income & Albrecht (2006), Rezaee (2005), Coenen (2009) \\
\hline 4 & Unauthorized income or delivery & Coenen (2009), Hopwood et al. (2008) \\
\hline 5 & Exaggerated sales of real estate & $\begin{array}{l}\text { Coenen (2009), Rezaee (2005), Albrecht } \\
\text { (2006), Elder et al. (2010) }\end{array}$ \\
\hline 6 & $\begin{array}{l}\text { Credit sales are recognized by making an order at the end of the period, but the } \\
\text { goods have been sent even though the buyer has not ordered them }\end{array}$ & Hopwood et al. (2008) \\
\hline 7 & Record sales but the goods have not been sent in whole or in part. & Coenen (2009) \\
\hline 8 & There is money for the return of goods, but not properly recorded & Lord (2010) \\
\hline 9 & Goods returned from customers are not recorded & $\begin{array}{l}\text { Coenen (2009), Rezaee (2005), Albrecht } \\
\text { (2006), Elder et al. (2010) }\end{array}$ \\
\hline 10 & $\begin{array}{l}\text { A record that there is money coming in via bank transfer or manipulation as if } \\
\text { there was cash received from a customer }\end{array}$ & $\begin{array}{l}\text { Coenen (2009), Rezaee (2005), Albrecht } \\
\text { (2006), Elder et al. (2010) }\end{array}$ \\
\hline 11 & Not recording the discounted price given to the customer & $\begin{array}{l}\text { Coenen (2009), Rezaee (2005), Albrecht } \\
\text { (2006), Elder et al. (2010) }\end{array}$ \\
\hline 12 & Their consignment sales but accounted for as a sale completed & $\begin{array}{l}\text { Coenen (2009), Rezaee (2005), Albrecht } \\
\text { (2006), Elder et al. (2010) }\end{array}$ \\
\hline 13 & $\begin{array}{l}\text { It misses the sale limit date, manipulating a sales transaction in this period, } \\
\text { even though it is a sale of the next period }\end{array}$ & Hopwood et al. (2008) \\
\hline 14 & Acknowledge legitimate sales early & Coenen (2009) \\
\hline 15 & Form a sales order but the item being sent is delayed (billed and hold) & $\begin{array}{l}\text { Hopwood et al. (2008), Coenen (2009), Lord } \\
\text { (2010) }\end{array}$ \\
\hline 16 & $\begin{array}{l}\text { Making a fake agreement that changes the sales transaction clause that violates } \\
\text { the rules into a transaction that is considered according to an accounting rule }\end{array}$ & $\begin{array}{l}\text { Elder et al. (2010), Lord (2010) \& Coenen } \\
\text { (2009) }\end{array}$ \\
\hline 17 & $\begin{array}{l}\text { Inappropriate cut - off periods for transferring income among accounting time } \\
\text { range or period }\end{array}$ & $\begin{array}{l}\text { Elder et al. (2010), Lord (2010) \& Coenen } \\
\text { (2009) }\end{array}$ \\
\hline 18 & $\begin{array}{l}\text { Recording returns after the end of an accounting period to conceal the purchase } \\
\text { returns has an impact on the cost of goods sold }\end{array}$ & $\begin{array}{l}\text { Coenen (2009), Rezaee (2005), Albrecht } \\
\text { (2006), Elder et al. (2010) }\end{array}$ \\
\hline 19 & Write off bad debt in the next period & $\begin{array}{l}\text { Coenen (2009), Rezaee (2005), Albrecht } \\
\text { (2006), Elder et al. (2010) }\end{array}$ \\
\hline 20 & $\begin{array}{l}\text { At the end of the period, terminate a failed sales transaction with the aim of not } \\
\text { reducing the period's sales items }\end{array}$ & $\begin{array}{l}\text { Coenen (2009), Rezaee (2005), Albrecht } \\
\text { (2006), Elder et al. (2010) }\end{array}$ \\
\hline 21 & $\begin{array}{l}\text { The sales flow or benefits are hidden from the auditor to increase net income or } \\
\text { sales item }\end{array}$ & Elder et al. (2010), Rezaee (2005) \\
\hline 22 & Reducing allowance for doubtful accounts, to reduce debt items & $\begin{array}{l}\text { Coenen (2009), Rezaee (2005), Albrecht } \\
\text { (2006), Elder et al. (2010) }\end{array}$ \\
\hline 23 & Uncollectible receivables are not removed & $\begin{array}{l}\text { Coenen (2009), Rezaee (2005), Albrecht } \\
\text { (2006), Elder et al. (2010) }\end{array}$ \\
\hline
\end{tabular}

(Source: Recapitulation of recent studies , 2019) 
Table 2. How to appraise assets that are not appropriate

\begin{tabular}{|c|c|c|}
\hline No. & Techniques and Methods of Concealment & Sources \\
\hline 1 & Manipulating amount of physical inventory & Coenen (2008), Wells (2005), Albrecht (2006) \\
\hline 2 & Inflated unit of costs to increase the value of the inventory & Coenen (2008), Wells (2005), Albrecht (2006) \\
\hline 3 & $\begin{array}{l}\text { Outdated inventory and other assets did not record as adjusting for } \\
\text { impairment or billing issues }\end{array}$ & Coenen (2008), Wells (2005), Albrecht (2006) \\
\hline 4 & $\begin{array}{l}\text { The amount of inventory for the cost of goods sold is overstated. Usually } \\
\text { making fake documents such as counting sheets }\end{array}$ & Coenen (2008), Wells (2005), Albrecht (2006) \\
\hline 5 & $\begin{array}{l}\text { It is not appropriate to capitalize on inventory and cost of initial } \\
\text { inventory }\end{array}$ & Coenen (2008), Wells (2005), Albrecht (2006) \\
\hline 6 & Enlarge the component or do not reduce inventory costs & Coenen (2008), Wells (2005), Albrecht (2006) \\
\hline 7 & $\begin{array}{l}\text { Make a counterfeit record of the amount of inventory available for being } \\
\text { able to conceal it by fake shipments }\end{array}$ & Wells (2005), Albrecht (2006), Coenen (2008) \\
\hline 8 & Outdated and slow-moving inventories are recorded as misstatements & Jones (2011) \\
\hline 9 & The method for valuing inventories is changed according to interests & Jones (2011) \\
\hline 10 & $\begin{array}{l}\text { Manipulate the total production costs involved in calculating ending } \\
\text { inventory }\end{array}$ & Wells (2005), Jones (2011) \\
\hline 11 & Manipulating the presentation of inventory in the shipping process & Lord (2010) \\
\hline 12 & Outdated or unsold inventory is recognized & Lord (2010) \\
\hline 13 & $\begin{array}{l}\text { Inventory items are recorded in excess, by not removing obsolete } \\
\text { inventory or there are no reserves or reduce the value of inventory }\end{array}$ & Coenen (2009) \\
\hline 14 & $\begin{array}{l}\text { Manipulation of the recording of Accounts Receivable by recording } \\
\text { accounts receivable Fictitious }\end{array}$ & Coenen (2008), Wells (2005), Albrecht (2006) \\
\hline 15 & Receivables from receivables as bad loans are not written off & Coenen (2008), Wells (2005), Albrecht (2006) \\
\hline 16 & Trade receivables are added unilaterally & Wells (2005), Albrecht (2006) \\
\hline 17 & $\begin{array}{l}\text { Many fictitious assets are ordered to influence the total assets in the } \\
\text { balance sheet }\end{array}$ & Coenen (2008), Wells (2005), Albrecht (2006) \\
\hline 18 & Depreciation of assets is manipulated by changing the useful life of assets & Jones (2011) \\
\hline 19 & Depreciation is not recorded correctly & Coenen (2008), Wells (2005), Albrecht (2006) \\
\hline 20 & $\begin{array}{l}\text { The market value of fixed assets is presented even more supported by } \\
\text { fake asset valuation documents }\end{array}$ & Coenen (2008), Wells (2005), Albrecht (2006) \\
\hline 21 & $\begin{array}{l}\text { The cost of acquiring assets is magnified in collaboration with other } \\
\text { parties }\end{array}$ & Coenen (2008), Wells (2005), Albrecht (2006) \\
\hline 22 & Presenting securities accounts incorrectly with the help of a third party & Coenen (2008), Wells (2005), Albrecht (2006) \\
\hline \multirow[t]{7}{*}{23} & Manipulate returns or record returns in the previous period repeatedly & Coenen (2008), Wells (2005), Albrecht (2006) \\
\hline & Increase the price of fixed assets & Coenen (2008), Wells (2005), Albrecht (2006) \\
\hline & The impairment price of assets is not recorded & Coenen (2008), Wells (2005), Albrecht (2006) \\
\hline & The estimated fair market value of assets manipulated & Coenen (2008), Wells (2005), Albrecht (2006) \\
\hline & Manipulating Reserve funds & Coenen (2008), Wells (2005), Albrecht (2006) \\
\hline & Inaccuracy in investment appraisal by incorrect investment classification & Coenen (2009) \\
\hline & $\begin{array}{l}\text { Amounts that are attributable to mergers or acquisitions are not recorded } \\
\text { correctly }\end{array}$ & Coenen (2009) \\
\hline
\end{tabular}

(Source: Recapitulation of recent studies , 2019)

In addition to income, assets are one of the objects that can be manipulated in financial statements. Wells (2005) states that fraud on assets is usually to make the balances look healthier, especially to improve important ratios, for example, profitability, debt ratios, and the ratio of capital concerning assets. Important ratios such as profit ratios, debt ratios, capital capability ratios, and adequacy of funds are very dependent on the number of assets owned by the company. Fraudsters can use a variety of ways to appraise assets improperly, one of is the amount of physical inventory being manipulated (Coenen, 2008), unit costs will be raised for inventory prices (Albrecht et al., 2006) and misstatement of provisions for inventories with slow turnover and expired inventories (Jones, 2011). We have also summarized in Table 2 the various ways of fraud on assets.

Other items in the financial statements are liability items or commonly known as liabilities. Item liabilities or hidden costs are easier to manipulate than manipulating revenue or sales items through the falsification of transactions or moving the sales period. Auditors will have difficulty detecting hidden transactions rather than recording transactions improperly, due to difficulties in finding traces of fraud (Wells, 2005). We have summarized several ways 
of concealing costs or liabilities that come from previous literature and research in Table 3.

Improper disclosures usually involve the following: removal of liabilities, subsequent events, transactions with related parties, and accounting changes (Wells, 2005). Many studies (Henry et al., 2007; Rezaee \& Riley, 2010; Wahdan \& Herik, 2012) show that when corporate governance is weak, it will facilitate cooperation between related parties in the company thus further increasing non-ethical behavior and ultimately cheating. Research by Henry et al. (2007) concluded that the weakness of the public audit process is the inability to identify related party transactions, both with third parties and between sections within the company. Then the researchers added that the lack of information about a financial statement further reduced the user's ability to understand financial statements for evaluation.

Misstatements or failures in disclosures in financial statements that cause fraud include: weak rules or weak government investigations, potential warranty problems with products and services or debt of service, various events such as changes in product and service offerings or problems related to decreased demand for goods and services, the technology used by the company is out of date or obsolete, a decline in the value of the company's strategic investments, changes in accounting policies or principles in principle, making it difficult to compare values between accounting periods, negotiations have not been right with the related parties, and events after the closing of the book that has a significant influence on the opinion of the related parties.

To date, there has been little or no research attention in the context of details of how fraud has been committed in Indonesia. In the current research, the main focus is more on what the impact of fraud is, then why management is doing fraud, or the intention of management to reveal fraud, even in some developing countries in Asia and Africa. For example, one study concluded that executives in Egypt proved to prefer increasing income by using special methods to get large bonuses and trying to avoid taxes by lowering income (Dey et al., 2008). The Kaseem Study (2018) shows that management manipulates reports in the hope of high profits to increase the chances of obtaining a bank loan. More research in Indonesia is aimed at earnings management, while efforts to disclose Fraud and the Fraud mode have not been carried out.

Table 3. How to manipulate liability and costs

\begin{tabular}{|c|c|c|}
\hline No. & Techniques and Methods of Concealment & Sources \\
\hline 1 & $\begin{array}{l}\text { Efforts to reduce the amount of debt in this period, by transferring in the } \\
\text { next period. It can also prevent employees from recording the amount of } \\
\text { debt in this period }\end{array}$ & $\begin{array}{l}\text { Wells (2005), Coenen (2008; 2009), Sterling } \\
\text { (2002), Elder et al. (2010) }\end{array}$ \\
\hline 2 & $\begin{array}{l}\text { Not carried out correctly recorded liabilities such as service debt, } \\
\text { contingent liabilities or income received in advance }\end{array}$ & Coenen (2009) \\
\hline 3 & Obligations that should have existed were not raised & $\begin{array}{l}\text { AICPA (2007), Wells (2005), Coenen (2008; 2009), } \\
\text { Sterling (2002) }\end{array}$ \\
\hline 4 & $\begin{array}{l}\text { Accrued obligations or costs are recorded at this time, which should be in } \\
\text { the next period }\end{array}$ & $\begin{array}{l}\text { AICPA (2007), Wells (2005), Coenen (2008; 2009), } \\
\text { Sterling (2002) }\end{array}$ \\
\hline 5 & Income received in advance is recorded as pure income & $\begin{array}{l}\text { AICPA (2007), Wells (2005), Coenen (2008; 2009), } \\
\text { Sterling (2002) }\end{array}$ \\
\hline 6 & Cozy and Liabilities that are not recorded properly & $\begin{array}{l}\text { AICPA (2007), Wells (2005), Coenen (2008; 2009), } \\
\text { Sterling (2002) }\end{array}$ \\
\hline 7 & Not properly documented agreement items and repurchase commitments & $\begin{array}{l}\text { AICPA (2007), Wells (2005), Coenen (2008; 2009), } \\
\text { Sterling (2002) }\end{array}$ \\
\hline 8 & $\begin{array}{l}\text { Some liabilities and contingent costs are recorded in amounts that are too } \\
\text { low }\end{array}$ & $\begin{array}{l}\text { AICPA (2007), Wells (2005), Coenen (2008; 2009), } \\
\text { Sterling (2002) }\end{array}$ \\
\hline 9 & $\begin{array}{l}\text { The existence of ambiguity between current liabilities and long-term } \\
\text { obligations, the aim is to enlarge certain financial ratios for certain goals }\end{array}$ & $\begin{array}{l}\text { AICPA (2007), Wells (2005), Coenen (2008; 2009), } \\
\text { Sterling (2002) }\end{array}$ \\
\hline 10 & Purchases not recorded & $\begin{array}{l}\text { AICPA (2007), Wells (2005), Coenen (2008; 2009), } \\
\text { Sterling (2002) }\end{array}$ \\
\hline 11 & $\begin{array}{l}\text { Does not serve any return of purchases and purchase discounts to maintain } \\
\text { the cost of purchase }\end{array}$ & $\begin{array}{l}\text { AICPA (2007), Wells (2005), Coenen (2008; 2009), } \\
\text { Sterling (2002) }\end{array}$ \\
\hline 12 & Not well-recorded booking fees & $\begin{array}{l}\text { AICPA (2007), Wells (2005), Coenen (2008; 2009), } \\
\text { Sterling (2002) }\end{array}$ \\
\hline 13 & $\begin{array}{l}\text { Not recording the value of inventories, the value of receivables, or the } \\
\text { market value of buildings and fixed assets based on generally accepted } \\
\text { accounting principles }\end{array}$ & $\begin{array}{l}\text { AICPA (2007), Wells (2005), Coenen (2008; 2009), } \\
\text { Sterling (2002) }\end{array}$ \\
\hline 14 & $\begin{array}{l}\text { Reduction in costs by not reporting rebates, purchase returns, and discounts } \\
\text { of sales }\end{array}$ & $\begin{array}{l}\text { AICPA (2007), Wells (2005), Coenen (2008; 2009), } \\
\text { Sterling (2002) }\end{array}$ \\
\hline 15 & Keep a record of smaller expenses to avoid being detected & $\begin{array}{l}\text { AICPA (2007), Wells (2005), Coenen (2008; 2009), } \\
\text { Sterling (2002) }\end{array}$ \\
\hline 16 & $\begin{array}{l}\text { Treating sales accounts incorrectly, sales costs are converted to } \\
\text { non-operational costs, so it does not affect gross profit }\end{array}$ & $\begin{array}{l}\text { AICPA (2007), Wells (2005), Coenen (2008; 2009), } \\
\text { Sterling (2002) }\end{array}$ \\
\hline
\end{tabular}

(Source: Recapitulation of recent studies , 2019) 


\section{Method and Procedures}

The research design is a descriptive study even though there are non-parametric tests. Data collection uses a survey and interview approach. To achieve the objectives of this study, we collected data through online questionnaires and semi-structured interviews with respondents of external auditors at the Accounting Firm both affiliated with Big-4, non-affiliated and International Auditors working in Indonesia. We sent questionnaires to around 200 respondents. The questionnaire included items that asked respondents to be approved to be involved in interviews related to this study. Of the 200 questionnaires we sent, we only received sixty-eight questionnaires, with a response rate of only $34 \%$. Of the sixty-eight who returned the questionnaire, eighteen auditors agreed to be interviewed as informants. The current study uses a sequential mixed method research design and the first stage we collect data using an online questionnaire to target respondents, then select specific informants who are willing to interview.

Then we analyze a non-parametric statistical test for the relationship among the experience of an auditor in the audit process and the ability to disclose fraud in the preparation of Financial Statements. Data were analyzed using a phi-test analysis. Phi-test is an associative test on a nominal data scale if the contingency table is in the form of $2 \times 2$. So it can be said that the correlation coefficient phi is designed for dichotomous variables. The meaning of dichotomy is two nominal categories. The phi coefficient formula is explained below:

$$
\phi=\frac{a d-b c}{\sqrt{(a+b)(c+d)(a+c)(b+d)}}
$$

We interview the informant to help enrich the primary data that we collected through a questionnaire. This research technically requires confirmation from experienced auditors and at least only auditors who have worked at least 2 years that we use as informants in the interview process. Inexperienced informants certainly don't have enough answers to our questions, this trend is known as 'uninformative responses' (Saunders et al., 2009), which can reduce data reliability. Ten interview participants were conducted via telephone calls, the rest via Whatsapp Videocall. Interview sessions take around 20-25 minutes, and we record all results of interviews both written notes and voice recordings.

\section{Results and Discussion}

In the initial section, we present the survey results related to the auditor's experience, Classification of Public Accountant Firms, Professional Qualifications of Public Accountants and Job Public Accountants who are willing to be Audit Respondents' Experience being interviewed.
We summarize descriptively the respondents' demographic data that we present in Tables 4 to 9 below.

Table 4. Experience of auditor

\begin{tabular}{|c|c|c|}
\hline $\begin{array}{c}\text { Year Range on Audit } \\
\text { Experience Workfiled }\end{array}$ & Frequency & Percent (\%) \\
\hline 0 - 2 years & 3 & 4.41 \\
\hline 3 - 5 years & 12 & 17.65 \\
\hline 6 - 8 years & 25 & 36.76 \\
\hline Above 8 years & 28 & 41.18 \\
\hline Total & 68 & 100.0 \\
\hline
\end{tabular}

(Source: Authors calculation, 2019)

Table 5. Types of classification of accounting firms

\begin{tabular}{|c|c|c|}
\hline Types of Accounting Firms & Frequency & Percent (\%) \\
\hline Domestic Big-4 & 7 & 10.29 \\
\hline Domestic Non-Big-4 & 56 & 82.35 \\
\hline International Non-Big-4 & 5 & 7.35 \\
\hline Total & 68 & 100.0 \\
\hline
\end{tabular}

(Source: Authors calculation, 2019)

Table 6. Public accountant professional qualification

\begin{tabular}{|c|c|c|}
\hline & Frequency & Percent (\%) \\
\hline \multicolumn{3}{|c|}{ Public Accountant (Ak.) } \\
\hline No. & 2 & 2.94 \\
\hline Yes & 66 & 97.06 \\
\hline Total & 68 & 100.0 \\
\hline \multicolumn{3}{|c|}{ Chartered Accountants (CA) } \\
\hline No. & 15 & 22.06 \\
\hline Yes & 53 & 77.94 \\
\hline Total & 68 & 100.0 \\
\hline \multicolumn{3}{|c|}{ Certified Public Accountants (CPA) } \\
\hline No. & 43 & 63.24 \\
\hline Yes & 25 & 36.76 \\
\hline Total & 68 & 100.0 \\
\hline \multicolumn{3}{|c|}{ Certified Fraud Examiners (CFE) } \\
\hline No. & 59 & 86.76 \\
\hline Yes & 9 & 13.24 \\
\hline Total & 68 & 100.0 \\
\hline
\end{tabular}

(Source: Authors calculation, 2019)

Table 7. Job public accountants who are willing to be interviewed

\begin{tabular}{|c|c|c|}
\hline Job Public Accountants & Frequency & Percent (\%) \\
\hline Partner (Partner) & 1 & 5.56 \\
\hline Manager & 3 & 16.67 \\
\hline Senior Auditor & 10 & 55.56 \\
\hline Junior Auditor & 4 & 22.22 \\
\hline Total & 18 & 100.0 \\
\hline
\end{tabular}

(Source: Authors calculation, 2019) 
Table 8. Types of public accountant firm participants interviewed

\begin{tabular}{|c|c|c|}
\hline $\begin{array}{c}\text { Types of Classification of } \\
\text { Public Accounting Firms }\end{array}$ & Frequency & Percent (\%) \\
\hline Big-4 & 5 & 27.78 \\
\hline Domestic Non-Big-4 & 10 & 55.56 \\
\hline International Non-Big-4 & 3 & 16.67 \\
\hline Total & 18 & 100.0 \\
\hline
\end{tabular}

(Source: Authors calculation, 2019)

Table 9. Audit experience of respondents interviewed

\begin{tabular}{|c|c|c|}
\hline Experience Range & Frequency & Percent $(\%)$ \\
\hline $2-5$ years & 2 & 11.11 \\
\hline $6-9$ years & 5 & 27.78 \\
\hline $9-12$ years & 7 & 38.89 \\
\hline Above 12 years & 4 & 22.22 \\
\hline Total & 18 & 100.0 \\
\hline
\end{tabular}

(Source: Authors calculation, 2019)

The following will be presented the results of respondents' answers to some of the core issues related to fraud in the financial statements, which are sourced from questionnaires and interviews. Our findings reveal the majority of external auditors that fraud has occurred in the preparation of financial statements and are common, but they are not possible to disclose this $(66.17 \%, \mathrm{n}=45$ of 68 people). Various reasons were revealed why they were reluctant to disclose $(19.11 \% \mathrm{n}=14$ respondents $)$ explaining that auditors in Indonesia could not report fraud due to the following reasons: they fear for the work of the audit client, lack of protection, in particular, the organization of independent professionals, the weakness of the legal system in Indonesia, and the rights and obligations of auditors overlooked in the legal side. This finding supports the arguments of some experts who show that with the legal system and auditors are not responsible for what they have to say (Wahdan \& Herik, 2012; Anis, 2014). As in African countries, for example, weaknesses in the legal system are evident in the fact that accounting firms in Egypt, Senegal, and Nigeria rarely report their audit results to law enforcement. There are many risks of corruption when the legal system is weak. In the 2018 World Economic Forum, reported that companies have a great risk when the country has a weak legal system, and the survey results illustrate that the private sector was not satisfied with the legal conditions at that time. In some developing countries with weak legal systems, authorities develop legal and judicial systems as a way to not ensure a just society but to use law and justice as a means to justify and maintain the political status quo (Brown, 1997). While each country has its own rules relating to issues concerning the legal system and the legal rights of auditors, the first two reasons are strong reasons for the auditor's unwillingness to report fraud in the financial statements. As our experience, indeed there is almost no report from external auditors to law enforcement related to fraudulent financial statements, auditors choose to save this information, although they want to report only to the parties concerned in the company.

Various obstacles arise when auditors get irregularities over the financial statements, one of the obstacles is a conflict of interest. Conflicts arise for Auditors because they get audit fees and the decision to use the Accounting Firm depends on top management, so this conflict of interest becomes the auditor's consideration. It is concluded that the auditor's desire to raise the issue depends on opinions, interests, and things that have the potential to influence audit effectiveness and audit efficiency (Bloomfield et al., 2016). Auditors may face strong pressure to produce a professional performance, but also face a large audit risk (Cohen et al., 2000). Professional audits face a dilemma, on the one hand, they must maintain independence to stakeholders, but on the other hand, there is a desire from stakeholders to be implemented. We all believe that independence is the main thing in the audit, but long-term relationships also become something important for the Auditor. An inevitable fact is that the auditor's inability to oppose the illegal wishes of company management, and other facts that they are paid by the company (Kaseem, 2019). Audit independence becomes very expensive if these considerations continue to emerge until finally, the quality audit will decrease.

The application of the law is indeed important, but applying financial penalties to audit firms appears to be ineffective, given the increasingly widespread fraud on the company's financial statements, but the auditors are silent. Of course, sanctions or penalties can be imposed insofar as professional auditors do not depend on the mandate of the company providing audit services (Gaa, 1994). Situations, conditions, and individuals greatly influence the effectiveness of rules and punishment. With this situation, in the future, it will be a challenge for countries in the world to think about how the appropriate form of legal rules, so that the professionalism of audits can be maintained on the other side, the law can be upheld.

The results of our interviews with resource persons generally illustrate that fraud on financial statements has become commonplace. The auditor's opinion has several reasons including: (1) There is a fear that the employees, especially the accounting department, will lose their positions or even lose their jobs. Pressure from superiors to cheat is mostly followed by employees, for this reason; (2) The high competition of companies in the market, make the company must look at good performance, as a result of the company as far as possible makes financial statements look good; and (3) The high pressure for the company to obtain high profitability so that various efforts are made so that the al can be realized.

Specifically, at the time of the interview, the senior auditor mentioned that an employee is very easily persuaded to commit fraud, due to the consideration of the 
difficulty of finding work at the undergraduate or postgraduate level. With the capital of its accounting capability, the executive officer uses the employee's expertise for fraudulent purposes. This finding is in line with other studies that nearly $78 \%$ of adults in the UK are more important than earning high ethical standards (IBE, 2016). Even in 2015, for example, CGMA (2015) many employees said that they were under pressure to abandon ethics to act in the interests of short-term profits. Another thing also happened in Japan when the famous Japanese company Toshiba involved in an accounting scandal involving senior executives and internal accountants. A Toshiba executive rejected the notion that the US \$ 5.4 billion invested in Westinghouse in 2006 had weighed on finances, and led to book manipulation. Finally, in the United States a report from a Business Ethics survey, that many employees fear retaliation, dismissal, or other penalties for employees who disclose, so employees prefer not to report fraud and violations (Kareen, 2019).

This is a warning, meaning that with this condition the Accounting Firm in Indonesia needs to be more vigilant and focus on developing and improving integrity and ethics which will be very beneficial for controlling fraud. Many large cases in state-owned companies in Indonesia, the management of PT Kimia Farma in Indonesia made a profit of Rp 132 billion, which was reported in the 2000-2001 Financial Statements, the company used Accounting Firm Hans Tuanakotta \& Mustofa (HTM). However, the official at the time, the Ministry of SOEs and Bapepam there were irregularities in the Profit Report and contained elements of Fraud. After the re-audit, on October 3rd, 2002, in the new financial statement, the profit presented was only $\mathrm{Rp} 99.56$ billion, or lower $\mathrm{Rp} 32.6$ billion, or $24.7 \%$ of the reported initial profit. Public Accountants play an important role in supporting the manipulation of financial statement recording activities carried out by management. Professional ethics have been violated by Public Accountants.

In general, the manipulation of financial statements, or fraud is carried out because there is a lot of motivation behind it, such as the opinion of an informant in an interview that: "... manipulation in the financial statements is very high, much Top Management as the main actors because of a lot of pressure, especially pressure the acquisition of bonuses and the pressure of high profit earning from shareholders... ". This result is in line with several other opinions that management usually commits fraudulent actions on financial statements due to pressure from the owners in this case the dominant family ownership (Kaseem, 2018). Thus the finding of Makhaiel \& Sherer (2017) that management manipulates financial statements is caused by the large desire of investors, lenders, and employees to obtain a large profit target. The results of our survey found that $53 \%$ of respondents said they found fraud in financial statements, even more, the role of executive management in this action. The results of Kaseem's research (2019) also state that management has a greater chance of committing fraud, in addition to high earnings pressure, the hope of being maintained as an executive is also one of the reasons.

We tried to encourage informants in the interview to reveal as much detail as possible the frauds they had found, although not optimally, the auditor might not be willing to provide information, there were some important things that we managed to note including recognition of inadequate income which is the most common way done by my head in manipulating financial statements in Indonesia. The most common way of fraud is the recognition of manipulated income, applies to almost all countries in the world (COSO, 2018). For example Nissan in Japan, Tesco, and Patisserie Valerie in England (Lewis, 2019). Misuse of income accounts is the most common and relatively easy way and is rather difficult to be detected by the examiner, in this case, the External Auditor. Many reasons can be conveyed by the perpetrators so that this crime is disguised as if this is the right thing based on accounting principles. In 2018 OJK, Indonesia examined Bank Bukopin, according to the information of this case in the form of modification of credit card data at Bank Bukopin. This modification caused Bank Bukopin's commission-based credit position and income to increase improperly.

In addition to increasing revenue, the results show that inappropriate assets, besides revenue manipulation, asset valuation is the second most popular way to manipulate financial statements. As for the case in the UK, the collapse of the Carillion Construction Company has recently shown that asset valuations are inappropriate. Top management at Carillion that manipulates financial report by manipulation of the value of intangible assets is higher. Incorrect disclosure of assets also seems to be common in Indonesia as manipulation of income and assets. In 2019 the Indonesian Attorney General's Office revealed the alleged corruption in the management of PT Asuransi Jiwasraya's investment funds with the calculation of a state loss of around IDR 13.7 trillion and management Jiwasraya allegedly violated the principle of good corporate governance in managing public funds. The management of PT Asuransi Jiwasraya chose to invest at high risk to pursue large profits. The company places $22.4 \%$ of its financial assets or IDR. 5.7 trillion, mostly in companies with poor performance.

There is a significant issue: the auditor's experience related to the ability to disclose fraud. We use the Crosstab analysis and the phi test to explore the relationship between experience and the possibility of finding fraud in the audit process (see Table 10). 
Table 10. The method used to conduct a fraudulent financial reporting scheme in indonesia

\begin{tabular}{|c|c|}
\hline No. & Explanation \\
\hline \multirow[t]{2}{*}{1} & Incorrect asset valuation \\
\hline & $\begin{array}{ll}\text { Excessive inventory } \\
\text { - } & \text { Excess of fixed assets } \\
\text { - } & \text { Capitalize interests } \\
\text { - } & \text { Miscessive inventory } \\
\text { - } & \text { Work-in-process projects are financed through loans } \\
\text { - } & \text { Firms destment is not calculated and recorded properly } \\
\text { - } & \text { Capitalize costs } \\
\text { - } & \text { Adjusting entries are manipulated to record large asset values } \\
\text { - } & \text { Fixed assets are reported to be greater than the actual value } \\
\end{array}$ \\
\hline \multirow[t]{2}{*}{2} & Incorrect revenue recognition \\
\hline & $\begin{array}{l}\text { Manipulate the Revenue value to get a bonus } \\
\text { - The estimated value of income is manipulated } \\
\text { - } \quad \text { Income not yet common is recorded as real income } \\
\text { - } \quad \text { Avoid paying taxes by recording low income } \\
\text { - Revenue deferred to the next period } \\
\text { - } \quad \text { Record false discounts on purchases of goods, } \\
\text { - } \quad \text { Making fictitious sales agreements } \\
\text { - } \quad \text { Trade receivables are transferred either to the beginning or to the next period } \\
\text { - } \\
\text { Allowance for doubtful accounts is manipulated for accrual income }\end{array}$ \\
\hline \multirow[t]{2}{*}{3} & Covert liability \\
\hline & $\begin{array}{cl}\text { Manipulation in contingent liability and allowance } \\
\text { - } & \text { Not recording tax costs and tax obligations } \\
\text { - } & \text { Short-term to long-term loans are misinterpreted, to minimize liabilities } \\
\text { - } & \text { Installments of underpaid liabilities } \\
\end{array}$ \\
\hline \multirow[t]{2}{*}{4} & Hidden fees \\
\hline & $\begin{array}{l}\text { Avoid paying taxes by increasing expenses } \\
\quad \quad \text { Not recording the costs that should be recorded }\end{array}$ \\
\hline \multirow[t]{2}{*}{5} & Incorrect disclosure \\
\hline & $\begin{array}{cl}\text { Not disclose: } \\
\text { - } & \text { All transactions with interested parties with the company } \\
\text { - } & \text { Sources of capital and corporate finance } \\
& \text { Additional allowances for directors } \\
\end{array}$ \\
\hline
\end{tabular}

(Source: Own determination, 2019)

The survey results show that auditors $(\mathrm{n}=12,17.6 \%)$ stated that more small and medium-sized companies were cheating, family companies, and companies that were not listed on the Indonesia Stock Exchange (IDX), then also some family-owned companies and companies prepare consolidated financial statements. This is somewhat different from the ACFE report (2016) in other countries, especially Africa and the Middle East, the alleged Fraud is mostly carried out by Large and Listed Companies in the Exchange. Even though the results of the ACFE survey are only the scope of a few African countries, their findings cannot be generalized. Other respondents $(n=18,26.47 \%)$ said they believed that fraud in financial reporting could be reduced if there were joint shares, meaning that the shares had an evenly distributed or large-scale company, then companies must use Accounting Firm affiliated with Big-4 and companies that are under FSA's supervision. Accounting Firm auditors affiliated with Big- 4 play role in the governance of a good company in a situation where lack of political rights and conditions of political power quite influential (Leung \& Verriest, 2015) which of course is still suitable for the conditions of the Indonesian state. This implies that the company audited by the auditor of an Accountant Office affiliated with Big-4 in Indonesia is quite safe from fraud. The existence of Big-4 Accounting Firm has a guarantee of audit quality and has a greater survival expectancy than not Big-4 Accounting Firm (Chen et al., 2016). 
Table 11. Crosstab of the audit experience variable and the ability to find fraud during the audit process

\begin{tabular}{|c|c|c|c|c|c|c|}
\hline \multirow{2}{*}{ Explanation } & & \multicolumn{4}{|c|}{ Year of Audit experience } & \multirow{2}{*}{ Total } \\
\hline & & $0-2$ years & 3-5 years & 6-8 years & Above 8 years & \\
\hline \multirow{2}{*}{$\begin{array}{l}\text { Likelihood of detecting financial } \\
\text { reporting fraud }\end{array}$} & No & 1 & 6 & 6 & 7 & 20 \\
\hline & Yes & 2 & 7 & 13 & 26 & 48 \\
\hline Total & & 3 & 13 & 19 & 33 & 68 \\
\hline
\end{tabular}

(Source: Authors calculation, 2019)

Table 12. Phi-test results: the relationship between the auditor's experience and the ability to find fraud

\begin{tabular}{|c|c|c|c|c|}
\hline \multicolumn{5}{|c|}{ Symmetric measures } \\
\hline Explanation & & Values & Approximate Significance & Exact Significance \\
\hline \multirow{2}{*}{ Nominal by nominal } & \multirow{2}{*}{ Phi Cramer's V } & 0.28 & 0.132 & 0.136 \\
\cline { 3 - 5 } & & 0.28 & 0.132 & 0.136 \\
\hline \multicolumn{2}{|c|}{ Number of valid cases } & 68 & & \\
\hline
\end{tabular}

(Source: Authors calculation, 2019)

Our test results are presented in Tables 11 and 12 which show that, although the ability to find fraud is related to the experience of an auditor, the relationship is still weak. These results indicate indeed the ability and audit experience can detect fraud in financial statements. The results of this analysis also show that all auditors who have CFE (Certified Fraud Examiners) have succeeded in detecting and finding both intentional and inadvertent misstatements in the preparation of financial statements. Continuous professional development must focus on developing analytical and forensic skills and the Accounting Firm must be more aware of future changes, have more predictive capabilities, and try to warn companies that in the future the company is likely to collapse (Barac et al., 2016). There is evidence from Asare et al. (2015) research that most auditors cannot understand fraud risk, while knowledge related to fraud, training, and experience are important assets in detecting fraud.

To improve the ability of auditors to read Fraud cues in financial statements, we use motivated reasoning theory, which states that a decision-maker unexpectedly makes a path to achieve his goals, but can be realized if they maintain the objective illusions they have (Pyszczynski \& Greenberg, 1987; Kunda, 1990; Kadous et al., 2003). Starting from here, we have a positive prejudice that the Auditor is not unable to detect fraud, but there is a deception instruction that invites a negative resonance from the effort to detect fraud, meaning this way the auditor may understand that a transaction is manipulated, but there is a hope that fraud can occur due to misunderstanding of the perpetrators. Secondly, there is an inaccuracy which considers that it is only the negligence of the perpetrators, so that it is considered to be a misstatement. We try to use another analogy related to the auditor's experience in detecting fraud. In many psychology liters related to how the officer whether is a policeman, prosecutor, and even the Auditor there are pessimistic reasons for being able to expose a crime. Even the Police and Prosecutors themselves rarely succeed fully in crimes being investigated (Bond \& DePaulo, 2008). We can explore an even, for example, the Police and the Prosecutor only occasionally meet a suspect and only then do they meet during a crime, unlike the Auditors who can interact with clients each year, and there is a deep sense of friendship, it will be difficult to uncover the mistakes of "friends".

\section{Conclusions}

The case of financial statement fraud is a case applied throughout the world, including Indonesia. Our findings also show that fraud in Indonesia is more likely to be small and medium-sized businesses, then not public companies and the incidences of concentrated shareholders or family ownership, and companies that have many subsidiaries or consolidated financial statements.

Another finding we present is that there is a possibility that fraud can be detected by experienced and competent auditors, especially those who are certified, fraud examiners. In contrast to auditors who are not CFE certified specifically for the competency to detect fraud, it is rather difficult to understand disguised forms of fraud. This shows the importance of education and fraud detection competence is very helpful for auditors to detect fraudulent financial statements. Therefore, this study recommends that the Accounting Firm should establish a fraud risk assessment task for the most experienced auditors or those with CFE qualifications or equivalent. Meanwhile, professional audit institutions or universities should also consider incorporating anti-fraud education into the education program.

Future research opportunities must be able to explore other forms and contexts not only in financial statements but also in governance and supplier relationships. Other areas related to the ability to detect fraud have also not been 
done much, specifically how the effectiveness of auditors to disclose fraud without regard to aspects of audit fees, management pressure, and friendly relations between the Accounting Firm and the Company. The case of Indonesia is still high in its Fraud case, there must be a formula that is effective in how to uncover cases that occur specifically in corporate governance. The limitations of this study are several things, among others, we still include external auditors as a sample, but not to the company's internal auditors, although the challenges are relatively severe. Our survey online and maybe they are not auditors because they were not strictly controlled.

\section{Authors Contributions}

The authors listed have made a substantial, direct and intellectual contribution to the work, and approved it for publication.

\section{Conflict of Interest Statement}

The authors declare that the research was conducted in the absence of any commercial or financial relationships that could be construed as a potential conflict of interest.

\section{Acknowledgments}

This article was supported by the Faculty of Economics and Business (Mulawarman University) and Sekolah Tinggi Ilmu Ekonomi Samarinda. We are also grateful to the Editorial Board of the journal for providing the opportunity so that this article can be published comprehensively.

\section{REFERENCES}

[1] Albrecht, W. S., Albrecht, C. C., \& Albrecht, C. O. (2006). Fraud Examination. $2^{\text {nd }}$ ed. Boston: Cengage Learning.

[2] American Institute of Certified Public Accountants. (2007). Concealed liabilities: 1-7. Retrieved from http:// www.aicpa.org.

[3] Anis, A. (2014). Auditors' Perceptions of Audit Firm Rotation Impact on Audit Quality in Egypt. Accounting and Taxation, 6(2), 105-120.

[4] Asare, S. K., Wright, A., \& Zimbelman, M. F. (2015). Challenges Facing Auditors in detecting Financial Statement Fraud: Insights from Fraud Investigations. Journal of Forensic and Investigative Accounting, 7(2), 63 111.

[5] Association of Certified Fraud Examiners. (2005). Report to the Nation on Occupational Fraud and Abuse: 1-75.
Retrieved from http://www.acfe.com.

[6] Association of Certified Fraud Examiners. (2016). Tone at the top: How management can prevent fraud in the workplace, 1-80. Retrieved from http://www.acfe.com.

[7] Barac, K., Gammie, E., Howieson, B., \& Staden, M. V. (2016). The capability and competence requirements of auditors in today's complex global business environment. Great Britain: TJ International.

[8] Berle, A, A., \& Means, G. C (1932). The Modern Corporation and Private Property. New York: Macmillan.

[9] Bloomfield, B., Nelson. M. W., Soltes, E. (2016). Gathering Data for Archival, Field, Survey, and Experimental Accounting Research. Journal of Accounting Research, 54(2), 341-395.

[10] Bond, C. F., \& DePaulo, B. M. (2008). Individual Differences in Judging Deception: Accuracy and Bias. Psychological Bulletin, 134(4), 477-492.

[11] Brennan, N., \& McGrath, M. (2007). Financial Statement Fraud: Some lessons from US and European Case Studies. Australian Accounting Review, 17(42), 49-61.

[12] Brown, N. (1997). The Rule of Law in the Arab World: Courts in Egypt and the Gulf. Cambridge: Cambridge University Press.

[13] Chartered Global Management Accountant. (2015). Managing Responsible Business: The Ethical Challenges Organisations Must Navigate to Succeed in a Connected World, 1-23. Retrieved from https://www.cgma.org/resour ces/reports/2015- managing-responsible-business.html

[14] Chen, C., Gotti, G., Herrmann, D., \& Schumann, K. (2016). Earnings Quality of Foreign versus U.S. Reverse Mergers: Geographical location or Firm-level Incentives?. Journal of International Accounting Research, 15(1), 49-66.

[15] Coenen, T. (2008). Essentials of Corporate Fraud. Hoboken, NJ: John Wiley \& Sons.

[16] Coenen, T. (2009). Expert Fraud Investigation: A Step-by-Step Guide. Hoboken, NJ: John Wiley \& Sons.

[17] Cohen, J. R., Krishnamoorthy, G., \& Wright, A. M. (2000) Evidence on the Effect of Financial and Nonfinancial Trends on Analytical Review. Auditing Journal: Practice \& Theory, 19(1), 27-48.

[18] Committee of Sponsored Organisations of the Treadway Commission. (1987). Report of the National Commission on Fraudulent Financial Reporting, 1-79. Retrieved from http://www.coso.org

[19] Dey, C. R., Grinyer, J. R., Sinclair, C. D., \& El Habashy, H. (2008). Determinants of Accounting Choices in Egypt. Journal of Applied Accounting Research, 8(3), 48-92.

[20] Elder, R. J., Beasley, M. S., Arens, A. A. (2010). Fraud auditing. Auditing and Assurance Services: An Integrated Approach. $13^{\text {th }}$ ed. New Jersey: Pearson.

[21] Gaa, J. C. (1993). The Ethical Foundations of PublicAccounting. Vancouver: CGA-Canada Research Foundation.

[22] Henry, E., Gordon, E., Reed, B., \& Louwers, T. (2007). The 
Role of Related Party Transactions in Fraudulent Financial Reporting. Journal of Forensic \& Investigative Accounting, 4(1), 186-213.

[23] Hopwood, W. S., Leiner, J. J., \& Young, G. (2008). Forensic Accounting. New York: McGraw-Hill.

[24] Jones, M. (2011). Creative Accounting, Fraud, and International Accounting Scandals. In The Atrium, Southern Gate. Chichester. London: John Wiley \& Sons.

[25] Kadous, K., Kennedy, S. J., \& Peecher, M. E. (2003). The effect of quality assessment and directional goal commitment on auditors' acceptance of client-preferred accounting methods. Accounting Review, 78(3), 759-778.

[26] Kassem, R. (2018). Exploring External Auditors' Perceptions of the Motivations behind Management Fraud in Egypt-A Mixed Methods Approach. Managerial Auditing Journal, 33(1), 16-34.

[27] Kassem, R. (2019). Understanding financial reporting fraud in Egypt: evidence from the audit field. Third World Quarterly, 40(11), 1996-2015.

[28] Kunda, Z. (1990). The case for motivated reasoning. Psychological Bulletin, 108(3), 480-498.

[29] Leung, E., \& Verriest, A. (2015). The Impact of IFRS 8 on Geographical Segment Information. Journal of Business Finance \& Accounting 42(3), 273-309.

[30] Lewis, 1. (2019). Nissan's Parable of Shoddy Governance. Financial Times. Retrieved from https:/www.ft.com/conte nt/ d6aca7b8-39d9-11e9-9988-28303f70fcff .

[31] Lord, A. T. (2010). The Prevalence of Fraud: What Should We, As Academics, Be doing to Address the Problem? International Journal of Accounting \& Information Management, 19(2), 4-21.

[32] Makhaiel, N., \& Sherer, M. (2017). In the Name of Others: An Investigation of Earnings Management Motives in Egypt. Journal of Accounting in Emerging Economies, 7(1), 61-89.

[33] Mohamed, N., \& Handley-Schachelor, M. (2014). Financial statement fraud risk mechanisms and strategies: the case studies of Malaysian commercial companies. Procedia Social and Behavioral Sciences, 145, 321-329.

[34] Omoolorun, A. J., \& Abilogun, T. O. (2014). Fraud Free Financial Report: A Conceptual Review. International Journal of Academic Research in Accounting, Finance and Management Sciences, 7(4), 83-94.

[35] Pyszczynski, T., \& Greenberg, J. (1987). A biased hypothesis testing model of motivated attributional distortion. In L. Berkowitz (Ed.), Advances in Experimental Social Psychology, 20, 297-340. New York: Academic Press.

[36] Rezaee, Z., \& Riley, R. (2010). Financial Statement Fraud: Prevention and Detection. $2^{\text {nd }}$ ed. Hoboken, New Jersey: John Wiley \& Sons.

[37] Saunders, M., Lewis, P., \& Thornhill, A. (2009). Research Methods for Business Students. $5^{\text {th }}$ ed. Edinburgh Gate: Pearson Education Limited.

[38] Snyder, P. J., Priem, R. L., \& Levitas, E. (2009). The Diffusion of Illegal Innovations Among Management Elites. In Academy of Management Proceedings, 1, 1-6. Briarcliff Manor: Academy of Management.

[39] Sterling, T. F. (2002). The Enron Scandal. New York: Nova Science Publishers.

[40] Suyanto, S. (2014). Fraudulent Financial Statement: Evidence from Statement on Auditing Standard No. 99. Gadjah Mada International Journal of Business, 11(1), 117-144.

[41] The Institute of Business Ethics. (2016). Surveys on Business Ethics Briefings: 1-10. Retrieved from https://www.ibe.org.uk/userassets/briefings/b56 surveys20 16.pdf.

[42] Wahdan, M. A, \& Herik, H. J. (2012). Egyptian auditing investigated: diagnoses and remedies. International Journal of Economics and Accounting, 3(3-4), 365-385.

[43] Wells, J. T. (2005). Principles of Fraud Examination. Hoboken, New York: John Wiley and Sons. 